\title{
FROM HIGH SCHOOL TO UNIVERSITY: A REVIEW ON TRANSITION, CORRELATION, AND PERCEPTIONS
}

\author{
Nihta V. F. Liando \\ English Education Department \\ Faculty of Languages and Arts \\ Manado State University \\ Email: nihta02@yahoo.com
}

\begin{abstract}
ABSTRAK
Artikel ini memaparkan suatu kajian tentang transisi antara sekolah menengah atas dan universitas. Tujuan dari artikel ini adalah untuk menyajikan sebuah gambaran yang jelas tentang berbagai penelitian yang membahas isu-isu transisi, dengan memberikan deskripsi penelitian yang telah dilakukan, terutama yang berkaitan dengan korelasi antara SMA dan universitas. Lebih khusus lagi, artikel ini memberikan gambaran apakah performansi bahasa Inggris siswa di SMA berpengaruh pada saat mereka belajar bahasa Inggris pada tahun pertama universitas. Untuk melengkapi pembahasan, beberapa penelitian menyangkut persepsi mahasiswa tentang peralihan dari SMA ke unversitas, khususnya pengalaman mereka menjalani pendidikan di SMA turut dikemukakan dalam artikel ini.
\end{abstract}

Kata kunci: SMA, universitas, transisi, persepsi

\section{A. INTRODUCTION}

Attending university can be seen as a major decision people make in life. When young adults decide to continue studying in tertiary education, it shows that they are ready to play more important role in their life since such decision will influence their future life. Probably at the same time, they also decide to leave parents' house and live by themselves or with friends. In short, what they decide at this stage will more or less impact on their life later. This period of time can be regarded as a transition from being dependent to being more independent. Greene, Wheatley, and Aldava (1992) noted 4 major life transition events, namely (1) leaving home, (2) occupying an instrumental role, (3) marriage and the last (4) parenthood. The decision most young adults make when they finish high school such as continue to university and at the same time leave parents home falls into the first two categories of Greene. The second category of
Greene - taking up an instrumental role - can also be interpreted as starting to work. It is understood that young adults, at this stage, would like to perform more influential functions and be recognized as more mature persons by their parents, for example.

\section{B. TRANSITION FROM SCHOOL TO TERTIARY EDUCATION}

University life is different from high school life, whether it is in social relationships or academic matters. When high school students enter this new environment, adjustment is very important for them in order to survive. Sanders (1957) wrote that 'most first-year students find themselves translated from small class in which, as seniors, they received individual attention at school, into very large classes in which they are ciphers, as well as juniors, in the universities' (p.163). This surely requires efforts from students themselves to understand and to cope with things they have 
never encountered before. Brower (1992) argued that student adjustment means "the students' ability to agree with the expectations of the university and their ability to shape their college environment to meet their expectations" (p.456). Thus, students must work hard during their beginning semesters in order to successfully deal with the academic tasks as well as adjust with the new situation.

When looking at the literature on transition from school to university, most of the literature discussed difficulties students might face in the beginning year of their study, how students can cope with a new university environment that is different from what they have experienced in high school, or giving a possible solution that a university may adopt to minimize the problems. This has been the focus of research interest since the middle of $20^{\mathrm{m}}$ century. A study conducted by Olsen (1957) for instance, focused on students failing in the first year university examinations. His study was based on his research work mainly concerned with 250 students who failed in first year examination at the University of Queensland. His findings indicated that factors associated to students failing in university examinations were human reasons, some psychological and personal, some socio-economical and environmental. He also emphasised on the role of secondary school for university success. Prior to Olsen's, contribution to research in this field has been done by a number of people such as Eysenck (1935), Sanders (1948), and Hohne (1949). Their research findings suggested that inadequate preparation in the secondary school would cause failure in university examinations, besides some personality factors such as emotional stability, home conditions or worries about finance. Anderson (1961) cited a study by University of Melbourne investigating Victorian first-year-students studying in Melbourne that showed a significant association between level of students' performance in the first year university and their personal problems.

Powell (1976) in his paper discussed issues relating to selection and admission and the difficulties many Australian students facing during their first year at university. He argued that many students were unable to make a smooth transition from high school to university due to some problems such as, the use of high school certificate as a selection criterion. He also mentioned the lack of entry schemes to allow students identify their interests. The attitude of young people towards higher education was also one of the problems pointed out by Powell. Genn (1969) investigated some educational and psychological issues relevant to transition of students from school to university as they studied chemistry, such as how students achieved success and satisfaction in their first year studies at university by considering variables such as personality needs of students, the nature of the learning environment at school and university, and the congruence between personality need and college environment. In his study, Genn involved 135 first-year Medicine students at University of Queensland as his main sample who took Chemistry I class. The findings of this research showed the relevance of need-press theory to the problem of transition. It also indicated the potential power of the theory to help in finding a solution for other more complex problems in transition of students from secondary school to university. One of his arguments was that the nature of the university environment was one of the crucial elements to be successful and satisfactory in the first year of study in the university. Wieneke (1976) presented a study on the attitudes of students enrolling for the first time at the University of New South Wales towards higher education and anticipated difficulties in making transition from high school to university. Based on 2,973 responses, it was determined that most students have a fairly strong desire to attend the university and appear to be intellectually and/or vocationally committed to obtaining a degree. Findings indicated that the number of students who actually do better than just pass in all subjects is very small. It showed that there was a great discrepancy between how students expect to perform academically and how they do perform. 
More recent studies involving transition from school to college or university were from Terenzini, Rendon, Upcraft, Millar, Allison, Gregg, \& Jalomo, (1994), Tracey \& Corlett (1995), Wagner and Blackorby (1996), Lord and White (2001), and Nardi (2001). Terenzini et al. (1994) did a study on how students become involved as they make the transition from work or high school to college. They described the results of a series of focusgroup interviews with 132 diverse, new students entering a community college; a liberal arts college; an urban commuter - those who did not live in residential colleges, a comprehensive university - selected based on institutional traits such as mission, size, curricular emphasis, type and the availability of residential facilities; and a large research university. The study was able to identify the people, experiences, and themes in the processes through which students became (or failed to become) members of the academic and social communities on their campus. Findings showed that the nature and dynamics of the process varied according to the student's social, family and educational background; personality; educational and occupational orientations and aspirations; the nature and mission of the institution being attended; the kinds of peers, faculty, and staff members encountered; the purpose and nature of those encounters; and the interactions of all these variables. Nardi (2001) described the new legislation in Italian education system -changes in the Italian school and university system that influence the shift from school to university. The change in the school system was to the exam students have to take at the end of upper secondary education, which now does not guarantee for university entry due to the reorganising higher education. This created problems to students wanting to pursue university education because the final grade obtained in upper secondary school cannot be considered as a predictive indicator of success in university entry test.

Research focused on solutions to problems that occur in transition from school to university is presented by Buck (1985) who described a program called "Summer Bridge" developed in the University of California San Diego. This program was specifically designed to assist new students in coping with the university environment. The target students were those who had low-incomes who were educationally and culturally disadvantaged, or from minority ethnic groups who had poorer academic performance and retention rates. A similar program has been introduced in Adelaide University (Cargill, 1996; McGowan, Seton, \& Cargill, 1996) to help international students coping with new environment. The program was to assist international graduate students in adjustment to Australian academic and discipline-related norms. It focused on language and academic skill development. The result showed that this integrated bridging program has successfully tackled the communication problem generated by the induction of foreign students into Australian academic institutes and has been found to be effective.

Among all studies in the area of transition from school to university, only a few have focused on research involving both school and university elements. For instance Lord and White (2001) presented a collaborative program initiated by the University of Bath. The collaboration is with a group of schools and colleges to develop familiarity in teaching Maths both in school and university as one of the solutions to transition issues. In their study, Musyken and Berger (1982) presented a fourstep process model. This program tried to network the second language program in high school and college. Seven goals were established. These were: to provide additional educational experiences for foreign language students in the target language and corresponding culture, and additional information on career planning and cadet teaching; to ease the transition from high school to university; to suggest areas for improvement of both secondary and university curricula; to increase communication between secondary teachers and university professors as 
professional colleagues. Barton (1986) in her article proposed that high school teachers and college and university librarians should work together to help students make the transition between high school and higher education or work She described a program done in Moorhead, Minnesota where high school teachers and university librarians worked together to help students in transition period.

Both school and university should work together to support students in preparing for further study, as Olsen (1957) mentioned that 'success in university studies is dependent, to an increasing extent, upon the skills and knowledge acquired in the secondary schools' (p.185). Unfortunately, this does not happen yet in Indonesia. Secondary school and university do their own job separately. This is reflected in the structure of organization applied in the Ministry of National Education where secondary school is under the Directorate of Basic and Middle Education while university is under the Directorate of higher Education. Therefore this study intends to investigate further the possibility to increase students' successfulness in their beginning year of studying in university by investigating both school and university with regards to participants (students, high school teachers, lecturers) and their perceptions and attitudes, curriculum issues, and pedagogy. Some of the seven goals established by Musyken and Bergen such as to ease the transition from high school to university and to suggest improvement in English curriculum both high school and university are relevant to this research project. In the next section, studies on the correlation between high school and university will be reviewed.

\section{CORRELATION BETWEEN HIGH SCHOOLAND UNIVERSITY}

The focus of this part of literature review is to review research that has investigated the correlation between in high school and university with regards to school subjects, grades and students' background. Alters (1995) in his study found out that there is a significant correlation between physics course in high school and the college physics. Alters' study was an extended research of what Hart and Cottle (1993) did at Florida State University and added the variable of high school achievement. Hart and Cottle found out that students with exposure to a basic physics course in high school would have an advantage in college physics. Alters studied 238 students who took Physics for the Life Science course in the first year at the University of Southern California. He distributed a questionnaire designed to obtain information on high-school physics exposure and achievement that students filled in the first day of Physics class. The students were from 4 similar sections, two from 1993 fall semester and the other two from 1994 spring semester. They were administered identical exams at the end of the semester. Results showed that grades in this college physics course were significantly higher among those who had taken physics courses in high school compared to those who did not take high school physics courses. The findings suggested that students who took physics courses while they were in high school would do better when they took physics in college although this study also revealed that there was no statistically significant correlation between high school physics achievement (grade) and university physics achievement. Capoor (1982) did an evaluation in the nurse education program at Middlesex County College (MCC). The study revealed that high school grades and aptitude test scores were good predictors of program success, and biology and advanced nursing course grades, overall grade point average, and achievement test scores were good predictors of success on the LBE. The above-mentioned studies suggested that there is a correlation between continuing courses taught in different level of education, in this case, courses taught in high school and university. Since English is offered in both high school and university in Indonesia it is useful to conduct a study, which will look at students' English performance in high school and in the first year university and whether they significantly correlate each other. 
Some studies suggested that students' academic performance is influenced by their backgrounds. Therefore, besides discussing the correlation between high school and university performance, it is also important to explore students' socio-economic background as a factor affecting students' academic performance. Caiden (1964) wrote an article reviewing research done in the topic of student failure in Australian universities. She was able to identify factors affecting this failure where students' socio-economic background was one of them. Caiden (1964) mentioned that students from professional and business families tended to perform better in the first year of university than students from working class backgrounds. Capoor's (1982) study at Middlesex County College (MCC) New Jersey also focused on the relationship between student background and performance and between student performance in their course work on the Licensing Board Examination (LBE). One of the findings suggested that employment status of parents was significantly related to course performance. The finding of Rice's (1997) study which investigated the safety and the quality of the learning environment and student achievement in mathematics and science indicated that students from more stable and supportive home environments showed less academic difficulty as they progress through the transition. The most recent longitudinal study on Australian youth conducted by Marks, McMillan \& Hilman (2001) which examined the tertiary entrance performance of students in Year 12 in 1998 using data from the Longitudinal Surveys of Australian Youth (LSAY) project indicated in one of a number of their findings that socio-economic background had effects over academic performance. They found that socio-economic backgrounds had influence on students' academic performance.

Besides exploring the correlation between high school and university and factors influence students' performance in university, it is also worthwhile investigating students' perceptions and experiences, as they perceive the transition from high school to university because they are the ones who have direct involvement with this event. The following section will discuss the perceptions on moving from high school to university.

\section{PERCEPTIONS}

Perception is defined as "(1) the faculty of an individual resulting in accurate detection of significant or desired aspects of external reality through the senses, (2) a mental image or observation of external reality detected through the sense, (3) an insight or intuition" (The Concise Dictionary of Education, 1982). In this research project, students' perceptions means their actions and ability to express what they see, hear, based on their experience. Studies in transition from high school to university with a focus on students' perceptions have been conducted since the 60s. McFee (1961) undertook a study on the relationship of students' needs to their perceptions of a college environment. College Characteristics Index (CCI) and Activities Index (AI) established by Stern (1958) were used as the instruments. One hundred students in introductory psychology classes at Syracuse University were surveyed. However, this study failed to find any correlations between scale scores of individuals on the CCI and their parallel scores on the AI and no strong relation was found between personality need and the students' perception of college environment. A recent study on students' perceptions on transition was carried out by Birnie-Lefcovitch (2000). Her population sample comprised 651 firstsemester, full-time students enrolled in Biological or Environmental Science programs at a university in south - western Ontario who were given a closed-ended questionnaire at two points in time. From this population, 497 individuals completed and returned the survey at Time 1, and a total of 453 did likewise at Time 2. The first questionnaire was distributed immediately after the individual's acceptance to the offer and the second questionnaire (similar to the first one, only a slight change was made in terms of time) was given after they completed the first semester. Birnie-Lefcovitch 
reported that $74.2 \%$ of respondents at Time 1 and $72.1 \%$ at Time 2 viewed the transition as a 'normative life event'. She argued that normative transitions "generally can be anticipated and prepared for in advance" and "they fundamentally alter the way in which individuals view themselves and their world" (Birnie-Lefcovitch, 2000, p.62). What is more interesting in her findings is the level of concern in particular areas such as the way the students felt they interpersonal relationships might change, the length of time they took to adjust and the range of stresses associated with the first semester which varied depending on the students' social background.

A case study conducted by Harklau (2001) examined how individuals experienced and perceived the transition from high school to college. This longitudinal case study involved four female language-minority students who were followed through their last semester of high school and first semester in college. The results indicated that what the students found new or more challenging in college literacy practices was not necessarily predicted in a developmental perspective but was better understood as contextualized to their high school literacy experiences. In her article, Drew (2001) reported the findings of the project she did in the early 90 s involving 263 university students. This project was to explore students' perceptions of what helped them learn and develop in higher education through group discussions. It could identify factors students considered influenced their learning. The findings suggested there were 4 student factors: (1) self-management, (2) motivation and needs, (3) understanding, and (4) support; and 3 contextual areas: (1) course organisation, resources and facilities, (2) assessment, and (3) learning activities and teaching.

Besides investigating students' perceptions, finding out their schooling experiences prior to university level would be considered beneficial since it could help universities to provide appropriate assistance to their new students. Thompson and Joshua-
Shearer (2002) conducted a study in which 156 university students - Hispanic and African American backgrounds - were questioned about their high school experiences. The findings indicated that many of the students had positive high school experiences however there was a need to improve some areas such as Maths, Science, study skills and increasing greater access to college preparatory courses.

Having discussed students' perception, it is also important to discover teachers and lecturers' perceptions since this is also part of the research project. In terms of student-teacher interaction concerning examination, Schonell, Roe and Meddleton (1962) stated that secondary teachers often concentrate unduly on types of questions likely to be asked in the matriculation examination, so that the student may have little need to think for himself, and, when this is the case the result may well be an over-estimate of the student's potential capacity for university studies.

Genn (1969), in line with Schonell et al. remark, stated that "teachers feel a strong obligation to help their students pass this examination and form a strong alliance with their students in an attempt to beat or outwit the external examiner" (p.18). In terms of the transition from high school to university, Muysken and Berger (1982) in their study showed that secondary teachers have expressed clearly their concern about the importance of adequate preparation of students for college. Merill (2001) did a study on the access of adults to university, In her study she also explored lecturers' perspectives towards teaching adult students. Her findings indicated that most lecturers mentioned that they did not modify their teaching styles although they had adults in the group. Overall, most lecturers had positive reasons regarding teaching adults. Having discussed the perceptions towards moving from high school to university, next section will briefly explain one non-academic factor, which plays an important tole for students' success, a motivation. 


\section{E. CONCLUSION}

Having reviewed the literature in the area of transition from high school to university, it is hoped that a better understanding and basic information regarding the issue of transition from high school to university will be obtained. Finding out what students' perceptions are regarding the transition from high school to university will suggest high school and university authorities to think and arrange suitable action in order to assist these new students gain a confidence during their beginning of the study and cope with a new university environment. Obtaining information about students' schooling experiences prior to university will help the educators in deciding the best and most appropriate program for them when entering university academic life.

Furthermore, the review of students' attitudes, more specifically in related to the practice of teaching English as a foreign language and their perceptions and expectations towards continuing to higher education will enrich knowledge on this topic.

\section{REFERENCES}

Alters, B. J. 1995. Counseling Physics Students: A Research Basis. Physics Teacher, 33(6), 413-415.

Anderson, D. S. 1961. Non-intellectual Correlates of Academic Performance. VESTES, 4(2), 42-46.

Bacon, S. M and Finneman, M. D. 1990. A Study of the Attitudes, Motives, and Strategies of University ForeignLanguage Students and Their Disposition to Authentic Oral and Written Input. Modern Language Journal, 74(4), 459-473.

Barton, M. A. 1986. Smoothing the Transition. Clearing House, 59(6), 254-255.

Birnie-Lefcovitch, S. 2000. Student Perceptions of the Transition from High School to University: Implications for Preventative Programming. Journal of the FirstYear Experience \& Students in Transition, 12(2), 61-88.
Brower, A. M. 1992. The "Second Half" of Student Integration: The Effects of Life Task Predominance on Student Persistence. Journal of Higher Education, 63(4), 441-462.

Buck, C. B. 1985. Summer Bridge: A Residential Learning Experience for High Risk Freshmen at the University of California, San Diego. Paper presented at the Annual Meeting of the National Conference on the Freshmen Year Experience,

Caiden, N. 1964. Student Failure in Australian Universities: A Bibliographical Review. VESTES, 7(1), 35-55.

Capoor, M. 1982. An Evaluative Study of the Nurse Education Program. Research Report Number 82-1: Middlesex County Coll, Edison, NJ Office of Research and Planning.

Cargill, M. 1996. An Integrated Bridging Program for International Postgraduate Students. Higher Education Research and Development, 15(2), 177-188.

Clement, R., Dornyei, Z., and Noels, K. A. 1994. Motivation, Self-Confidence, and Group Cohesion in the Foreign Language Classroom. Language Learning, 44(3), 417-448.

Drew, S. 2001. Student Perceptions of What Helps Them Learn and Develop in Higher Education. Teaching in Higher Education, 6(3), 309-331.

Gardner, R. C.,and Lambert, W. E. 1959. Motivational Variables in Second Language Acquisition. Canadian Journal of Psychology, 13, 266-272.

Gardner, R. C., and Lambert, W. E. 1972. Attitudes and Motivation in SecondLanguage Learning. Rowley, MA: Newbury House.

Genn, J. M. 1969. Chemistry Scholars in School and University Contexts - A Study of Transition from School to University. Unpublished $\mathrm{PhD}$, University of Queensland, St Lucia.

Hubungan Etnis Jawa dan Tionghoa dalam Novel Tunggak-Tunggak Jati (Yulitin Sungkowati) 
Greene, A. L., Wheatley, S. M., and Aldava, J. F. 1992. Stages on Life's Way: Adolescents' Implicit Theories of the Life Course. Journal of Adolescent Research, 7(3), 364-381.

Harklau, L. 2001. From High School to College: Student Perspectives on Literacy Practices. Journal of Literacy Research, 33(1), 33-70.

Harris, D. 1940. Factors Affecting College Grades: A Review of The Literature, 1930-1937. Psychological Bulletin, 56, 125-166.

Hart, G. E., and Cottle, P. D. 1993. Academic Backgrounds and Achievement in College Physics. Physics Teacher, $31(6), 470$.

Kang, D. H. 2000. Motivation is Such a Complex Process in the EFL Foreign Language Classroom. Retrieved February 17,2005, from http://md2.csa.com/ids70/export.php? $\underline{\mathrm{SID}}=\mathrm{bf6814361 \textrm {c } 6 8 \mathrm { cdb } 5 3 1 \mathrm { d } 7 \mathrm { d } 2 4 \mathrm { d } 0 \mathrm { ee }}$ ca5e5\&mark id=cache\%3A12\&mark low $=100 \&$ mark high $=110 \&$ mark $=1$ $01 \&$ mark $=104$

Kyriacou, C., and Benmansour, N. 1997. Motivation and Learning Preferences of High School Students Learning English as a Foreign Language in Morocco. Mediterranean Journal of Educational Studies, 2(1), 79-86.

Laine, E. J. 1978. Foreign Language Learning Motivation: Old and New Variables. Paper presented at the The 5th Congress of L'Association Internationale De Linguistique Appliquee, Montreal.

Lord, K., and White, J. 2001. Face the University Challenge. The Times Educational Supplement (4447).

Marks, G. N., McMillan, J., and Hillman, K. 2001. Tertiary Entrance Performance: The Role of Student Background and School Factors (22). Melbourne: Australian-Council-for-EducationalResearch (ACER).
McFee, A. 1961. The Relation of Students Needsto Their Perceptions of College Environment. Journal of Educational Psychology, 52(1), 25-29.

McGowan, U., Seton, J., and Cargill, M. 1996. A Collaborating Colleague Model for Inducting International Engineering Students into the Language Aad Culture of a Foreign Research Environment. (Special Section on Diversity in Professional Communication). Transactions on Professional Communication, 39(3), 117-121.

Merrill, B. 2001. Learning and Teaching in Universities: Perspectives from Adult Learners and Lecturers. Teaching in Higher Education, 6(1), 5-17.

Morris, F. A. 2001. Language Learning Motivation for the Class of 2002: Why First-Year Puerto Rican High School Students Learn English. Language and Education, 15(4), 269-278.

Muyskens, J. A., and Berger, P. 1982. University and Secondary School Articulation: Four Steps for Creating a Resource Network. Paper presented at the Central States Conference on the Teaching of Foreign Languages.

Nardi, E. 2001. The Transition from School to University in Italy: Examination Reform and Outstanding Issues. Assessment in Education, 8(3), 339351.

Niederhauser, J. S. 1997. Motivating Learners at South Korean Universities. Forum, $35(1)$.

Olsen, F. J. 1957. Failure in First Year University Examinations. The Australian Journal of Education, 1(1), 175-186.

Oxford, R., and Jill, S. (1994). Language Learning Motivation: Expanding the Theoretical Framework. Modern Language Journal, 78(1), 12-28.

Powell, J. P. 1976. Tertiary Shock: From Schooling to Higher Education. 
(Tertiary Education Research Centre Monograph No. 10.). Australia.

Rice, J. K. 1997. Explaining the Negative Impact of the Transition from Middle to High School on Student Performance in Mathematics and Science: An Examination of School Discontinuity and Student Background Variables. Paper presented at the Annual Meeting of the American Educational Research Association (Chicago, IL, March 2428, 1997). Chicago, IL.

Sanders, C. 1957. University Selection: Its Theory, History, and Psychology. The Australian Journal of Education, 1(3), 145-167.

Schonell, F. J., Roe, E., and Meddleton, I. G. 1962. Promise and Performance: A Study of Student Progress at University Level. Brisbane: UQ Press.

Shaaban, K. A., and Ghaith, G. 2000. Student Motivation to Learn English as a Foreign Language. Foreign Language Annals, 33(6), 632-644.

Terenzini, P. T., Rendon, L. I., Upcraft, L. M., Millar, S. B., Allison, K. W., Gregg, P. L., and Jalomo, R. 1994. The Transition to College: Diverse Students, Diverse Stories. Research in Higher Education, 35(1), 57-73.
Thompson, G. L., \& Joshua-Shearer, M. (2002). In restrospect: What college undergraduates say about their high school education. The High School Journal, 85(4), 1-15.

Tracey, J., \& Corlett, J. (1995). The transition experience of first-year university track and field student athletes. Journal of the Freshman Year Experience, 7(2), 81-102.

Wagner, M. M., \& Blackorby, J. (1996). Transition from high school to work or college: How special education students fare. Future of Children, 6(1), 103-120.

Wangsotorn, A. (1978). Relationships of attitude, aptitude and background to the achievement in English of Thai first-year college students. Paper presented at the Fifth International Congress of Applied Linguistcs (AILA), Thailand.

Wen, X. (1997). Motivation and language learning with students of Chinese. Foreign Language Annals, 30(2), 235251.

Wieneke, C. (1976). Students entering the University of New South Wales in 1975: Attitudes, expectations, and aspirations. Australia: University of New South Wales (Australia). 